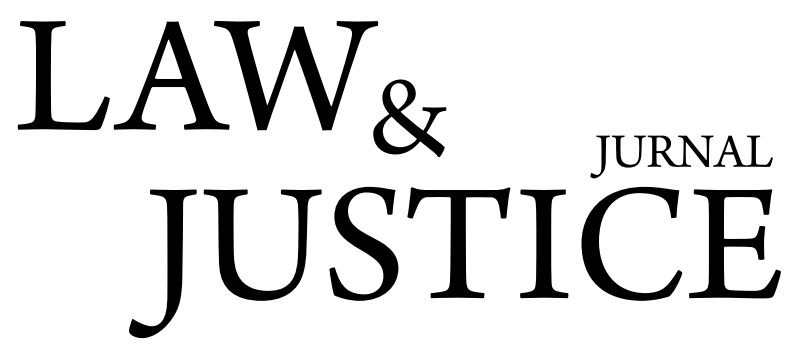

\title{
UPAYA PERLINDUNGAN HUKUM TERHADAP MEREK INDUSTRI UMKM DI INDONESIA
}

\author{
Andrew Betlehn \\ Program Studi Hukum Bisnis Universitas Agung Podomoro \\ Jalan Let. Jend. S Parman Kav. 28 Jakarta Barat, 11470 \\ Email: andrew.betlehn@podomorouniversity.ac.id \\ Prisca Oktaviani Samosir \\ Program Studi Hukum Bisnis Universitas Agung Podomoro \\ Jalan Let. Jend. S Parman Kav. 28 Jakarta Barat, 11470 \\ Email: prisca.samosir@podomorouniversity.ac.id
}

\begin{abstract}
Abstrak
Usaha Mikro, Kecil dan Menengah (UMKM) mempunyai peran penting dan strategis dalam pembangunan ekonomi nasional. Sebesar $60 \%$ (enam puluh persen) kekuatan ekonomi Indonesia ada di sektor industri UMKM. Jumlah UMKM di Indonesia pun setiap tahunnya mengalami peningkatan yang cukup signifikan. Akan tetapi, masih cukup banyak pelaku industri UMKM di Indonesia yang belum mendaftarkan merek dagangnya dikarenakan terbatasnya permodalan dan minimnya pemahaman akan manfaat pendaftaran merek bagi industri UMKM. Dengan demikian, UMKM yang tidak mendaftarkan merek dagangnya tidak mendapatkan perlindungan hukum, sebab suatu merek dagang akan mendapatkan perlindungan hukum jika telah melakukan pendaftaran merek. Dengan demikian, diperlukan kebijakan yang mengatur agar industri UMKM di Indonesia memperoleh perlindungan hukum terhadap merek dagangnya. Sehingga dalam penelitian ini akan meneliti mengenai bagaimanakah upaya perlindungan hukum terhadap merek industri UMKM di Indonesia. Adapun penelitian ini menggunakan metode penelitian yuridis normatif.
\end{abstract}

Kata Kunci: Perlindungan Hukum, Merek, Industri UMKM

\section{Pendahuluan}

Usaha Kecil Mikro Menengah (selanjutnya disebut UMKM) merupakan industri yang berkembang dengan sangat cepat dan besar di Indonesia. Industri UMKM menjadi salah satu pilar perekonomian yang menggerakkan roda perekonomian di Indonesia. Hal tersebut didukung dengan fakta yang didapatkan dalam kajian dari kementerian perindustrian di mana sektor UMKM mengambil konstribusi sebesar $60,34 \%$ terhadap produk domestik bruto di Indonesia pada tahun 2016. Fakta lain yang didapatkan adalah sektor UMKM dalam periode yang sama menyerap 97,22\% tenaga kerja di Indonesia. ${ }^{1}$

\footnotetext{
1 http://www.kemenperin.go.id/artikel/14200/Kontribusi-UMKM-Naik, diakses pada tanggal 4 Mei 2018.
} 
Meskipun demikian, sektor UMKM di Indonesia masih sangat identik dengan berbagai bisnis tradisional. Pada tahun 2018, hasil pencatatan Badan Ekonomi Kreatif ditemukan bahwa terdapat 96\% UMKM belum berbadan hukum ataupun memiliki payung hukum. ${ }^{2}$ Artinya, baik dalam bentuk usahanya ataupun bentuk badan hukumnya, mayoritas para pelaku usaha UMKM tidak berfokus kepada perlindungan hukum ataupun perkembangan usahanya melainkan kepada suatu keuntungan dan pola bisnis yang sederhana tanpa ada perencanaan pengembangan di masa mendatang. Selain itu, menurut Kepala Badan Ekonomi Kreatif, Triawan Munaf mengungkapkan bahwa para pelaku usaha tidak mendaftarkan usahanya untuk menghindari pajak usaha. ${ }^{3}$

Sektor bisnis tidak pernah dapat luput dari Kekayaan Intelektual. Setiap usaha yang dilakukan pasti memiliki kekayaan intelektual yang terdapat di dalamnya. Kekayaan Intelektual yang dimaksud dapat berupa Merek, Cipta, Paten, Desain Industri, Rahasia Dagang, Dasar Tata Letak Sirkuit Terpadu, dan Indikasi Geografis. Sama halnya dengan UMKM, meskipun skala bisnis yang dijalankan di dalam UMKM bukanlah suatu skala yang besar tetapi pada umumnya seluruh UMKM memiliki suatu Merek, baik Merek yang dipergunakan di dalam Perdagangan atau bisa disebut sebagai Merek dagang ataupun Merek yang dipergunakan di dalam suatu produk Jasa.

Merek merupakan tanda yang dapat ditampilkan secara grafis berupa gambar, logo, nama, kata, huruf, angka, susunan warna, dalam bentuk 2 dimensi atau 3 dimensi, suara, hologram, atau kombinasi dari 2 atau lebih unsur tersebut untuk membedakan barang dan atau jasa yang diproduksi oleh orang atau badan hukum dalam kegiatan perdagangan barang dan atau jasa. ${ }^{4}$ Dalam bisnis modern, suatu bisnis tidak dapat terlepaskan dari Merek dagang atau jasa karena Merek adalah identitas dari produk yang diperdagangkan. Sebagai identitas Merek merupakan suatu tanda pembeda antara produk barang atau jasa yang sejenis yang diperdagangkan oleh para pelaku usaha. Dengan adanya suatu Merek, maka konsumen juga dapat menentukan suatu pilihan dengan tidak adanya kebingungan.

Perlindungan merek di Indonesia menganut asas konstitutif (pendaftaran) dengan prinsip first to file. ${ }^{5}$ Artinya, Merek hanya mendapatkan perlindungan apabila Merek tersebut didaftarkan ke pemerintah melalui kementerian Hukum dan Ham dan dalam hal ini terdapat di Direktorat Kekayaan Intelektual. Apabila UMKM memiliki produk baik berupa barang maupun jasa dengan menggunakan suatu merek namun tidak didaftarkan, maka pelaku usaha UMKM tersebut kehilangan perlindungan hukum atas mereknya.

UMKM sebagai suatu industri berskala kecil masih menganggap bahwa perlindungan kekayaan intelektual bukanlah merupakan hal yang penting. Hal tersebut dibuktikan dengan masih minimnya pendaftaran Merek UMKM di Ditjen Kekayaan Intelektual. Data statistik pendaftaran Ditjen KI menunjukkan bahwa selama periode 2016-April 2018 pendaftaran Merek Non UMKM mendominasi sebesar 91,45\% sedangkan untuk merek UMKM hanya sebesar $8.55 \%{ }^{6}$ Padahal, menurut pandangan World Intellectual Property Rights (WIPO), UMKM memiliki banyak potensi untuk tumbuh kembang inovasi dan kreativitas atas produk. Namun, sayangnya kesadaran pengusaha UMKM akan pentingnya pemanfaatan Hak Kekayaan Intelektual untuk mendukung kegiatan usaha mereka masih rendah. $^{7}$

Disisi lain, identitas atau merek dagang sebagai salah satu wujud karya Intelektual memiliki peranan penting bagi kelancaran dan peningkatan perdagangan barang atau jasa. Hal ini tidak terlepas karena suatu merek digunakan untuk membedakan suatu barang tertentu dari barang lain yang bentuknya sejenis. Berbagai pemalsuan merek dagang untuk suatu barang sejenis dengan kualitasnya lebih rendah daripada barang yang menggunakan merek yang dipalsukan itu. Untuk memperoleh keuntungan secara cepat dan pasti sehingga merugikan pengusaha seperti UMKM yang memproduksi 2 https://ekonomi.inilah.com/read/detail/2443605/umkm-berbadan-hukum-masih-kecil,diakses pada tanggal 7 Mei 2018.

$3 \quad$ Ibid.

$4 \quad$ Pasal 1 angka 1 Undang-Undang No. 20 tahun 2016 tentang Merek dan Indikasi Geografis $5 \quad$ Khoirul Hidayah, Hukum Hak Kekayaan Intelektual, Jakarta : Setara Press, 2017, hlm. 54.

6 https://statistik.dgip.go.id/statistik/production/merek_umkm.php, diakses pada tanggal 7 mei 2018.

7 Agus Sardjono, "Pelaksanaan Perlindungan Hukum Merek Untuk Pengusaha UKM Batik Di Pekalongan, Solo, dan Yogyakarta", Jurnal Hukum dan Pembangunan. Volume 4 Oktober-Desember (2013). 
barang asli. Dengan memperhatikan hal tersebut di atas diperlukan suatu perlindungan merek barang-barang yang diproduksi UMKM. Berdasarkan uraian di atas, maka penulis dalam hal ini mencoba mengangkat suatu pokok permasalahan sebagai berikut: "Bagaimanakah upaya perlindungan hukum terhadap merek industri UMKM di Indonesia?".

Penelitian ini terbatas kepada penelitian yuridis normatif yang hanya menggunakan data sekunder berupa buku-buku kekayaan intelektual dan peraturan perundangan yang berlaku. Penelitian dan analisis terhadap permasalahan yang diangkat menggunakan metode berpikir induktif, di mana penulis berpikir berdasarkan hal-hal yang bersifat khusus kemudian pada akhirnya dibuat suatu kesimpulan yang bersifat umum dengan tetap memperhatikan berbagai asas dan kaidah hukum yang berkaitan dengan masalah yang di teliti.

\section{Pembahasan}

\section{Merek Sebagai Kekayaan Intelektual}

Merek merupakan salah satu kekayaan industri. Suatu produk tidak akan dapat terlepas dari suatu merek, karena merek merupakan identitas dari produk tersebut. Merek adalah aset ekonomi bagi pemiliknya, baik perorangan maupun perusahaan (badan hukum) yang dapat menghasilkan keuntungan besar, tentunya bila didayagunakan dengan memperhatikan aspek bisnis dan proses manajemennya yang baik. Demikian pentingnya peranan merek ini, maka terhadapnya dilekatkan perlindungan hukum, yakni sebagai objek terhadapnya terkait hak-hak perseorangan atau badan hukum. ${ }^{8}$

Pemegang atau pemilik Hak Merek yaitu orang atau persero, beberapa orang sebagai pemilik bersama dan Badan Hukum yang telah mendapatkan hak atas merek yang disebut dengan merek terdaftar. Terdapat beberapa tanda yang tidak boleh dijadikan merek, yakni sebagai berikut:

a. Merek yang tidak memiliki daya pembeda, misalnya hanya sepotong garis, garis yang sangat rumit, atau garis yang kusut.

b. Merek yang bertentangan dengan kesusilaan dan ketertiban umum, misalnya gambar porno atau gambar yang menyinggung perasaan keagamaan.

c. Merek berupa keterangan barang, misalnya merek kacang untuk produk kacang.

d. Merek yang telah menjadi milik umum, misalnya tanda lalu lintas.

e. Kata-kata umum, misalnya kata rumah atau kota. ${ }^{9}$

Perlindungan atas Merek atau Hak atas Merek adalah hak ekslusif yang diberikan negara kepada pemilik Merek yang terdaftar dalam daftar umum merek. Untuk jangka waktu tertentu ia menggunakan sendiri Merek tersebut ataupun memberi izin kepada seseorang, beberapa orang secara bersama-sama atau Badan Hukum untuk menggunakannya. Perlindungan atas Merek Terdaftar yaitu adanya kepastian hukum atas Merek Terdaftar, baik untuk digunakan, diperpanjang, dialihkan, dan dihapuskan sebagai alat bukti bila terjadi sengketa pelanggaran Merek Terdaftar. ${ }^{10}$

Merek merupakan suatu tanda pembeda atas barang atau jasa bagi satu perusahaan dengan perusahaan lainnya atau pemilik perorangan satu dan yang lainnya. Sebagai tanda pembeda maka merek dalam satu kualifikasi barang/jasa tidak boleh memiliki persamaan antara satu dan lainnya, baik pada keseluruhan maupun pada pokoknya. Pengertian persamaan pada keseluruhannya yaitu apabila mempunyai persamaan dalam hal asal, sifat, cara pembuatan dan tujuan pemakaiannya. Pengertian persamaan pada pokoknya yaitu apabila memiliki persamaan pada persamaan bentuk, persamaan cara penempatan, persamaan bentuk dan cara penempatan, persamaan bunyi ucapan. ${ }^{11}$

Merek atas barang lazim disebut sebagai merek dagang, yaitu merek yang digunakan atau ditempelkan pada barang yang diperdagangkan oleh seseorang atau beberapa orang atau badan hukum.

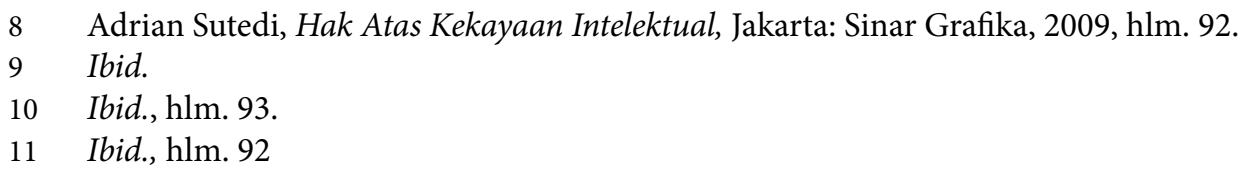


Merek sebagai tanda pembeda dapat berupa nama, kata, gambar, huruf, angka, susunan warna atau kombinasi dari unsur-unsur tersebut. ${ }^{12}$

\section{Urgensi Perlindungan Hukum terhadap Merek Industri UMKM di Indonesia}

Perlindungan merek sangat penting sekali, Merek berfungsi sebagai tanda pengenal yang menunjukkan asal barang dan jasa, sekaligus menghubungkan barang dan jasa yang bersangkutan dengan produsennya. ${ }^{13}$ Merek selain sebagai harta kekayaan yang dapat menghasilkan keuntungan bagi pengusaha selaku pemilik merek, juga sebagai alat untuk melindungi masyarakat selaku konsumen dari terjadinya penipuan kualitas barang tertentu. Konsumen akan meresa dirugikan jika merek yang mereka anggap berkualitas, ternyata diproduksi oleh pihak lain dengan kualitas rendah. ${ }^{14}$ Merek menggambarkan jaminan kepribadian (individuality) serta reputasi suatu barang dan jasa hasil usaha sewaktu diperdagangkan. ${ }^{15}$ Jaminan kualitas suatu barang atau jasa sangat berguna bagi produsen dalam persaingan usaha dan sekaligus memberikan perlindungan jaminan produknya kepada konsumen.

Dirjen KI mengemukakan bahwa pemakaian Merek berfungsi sebagai tanda pengenal untuk membedakan hasil produksi yang dihasilkan seseorang atau beberapa orang secara bersama-sama atau badan hukum dengan produksi orang lain atau badan hukum lainnya, kemudian sebagai alat promosi sehingga mempromosikan hasil produksinya cukup dengan menyebut Mereknya, sebagai jaminan atas mutu barangnya, dan sebagai penunjuk asal barang atau jasa yang dihasilkan. ${ }^{16}$

Oleh karena alasan-alasan diatas maka perlindungan hukum atas merek menjadi sangat penting agar tidak digunakan oleh pihak lain secara melawan hukum seperti pemalsuan, peniruan yang dapat menciptakan persaingan dagang tidak sehat dan pada akhirnya akan merugikan pemilik merek. Untuk memperoleh perlindungan hukum atas merek tersebut, maka dengan demikian maka Merek harus didaftarkan terlebih dahulu. Dirjen KI mengemukakan bahwa pendaftaran merek berfungsi sebagai alat bukti bagi pemilik yang berhak atas Merek yang didaftarkan, sebagai dasar penolakan terhadap Merek yang sama keseluruhan atau sama pada pokoknya yang dimohonkan pendaftaran oleh orang lain untuk barang atau jasa sejenisnya, dan juga berfungsi sebagai dasar untuk mencegah orang lain memakai Merek yang sama keseluruhan atau sama pada pokoknya dalam peredaran untuk barang atau jasa sejenisnya. ${ }^{17}$

Pentingnya pendaftaran merek terhadap pelaku usaha di Indoneisa belum secara menyeluruh disadari oleh kelas-kelas pelaku usaha. Di Indonesia terdapat kelas pelaku usaha seperti Usaha Mikro, Kecil dan Menengah (UMKM) yang mana secara persentase masih sedikit yang telah mendaftarkan merek ke Dirjen KI dibandingkan dengan pelaku usaha Non-UMKM. Sebagaimana data yang telah diuraikan sebelumnya yakni data statistik pendaftaran Ditjen KI menunjukkan bahwa selama periode 2016-April 2018 pendaftaran Merek Non UMKM mendominasi sebesar 91,45\% sedangkan untuk merek UMKM hanya sebesar $8.55 \% .^{18}$ Pelaku usaha UMKM berbeda dengan pelaku usaha Non-UMKM yang dapat dilihat dari skala modal, aset serta keuntungan tahunan yang diperoleh. UMKM berada di bawah naungan Kementerian Koperasi dan Usaha Kecil Menengah Republik Indonesia. Pengertian dan kriteria UMKM sesuai dengan Undang-Undang Nomor 20 Tahun 2008 tentang Usaha Mikro, Kecil dan Menengahh adalah sebagai berikut:

a. Usaha Mikro

Usaha Mikro adalah usaha produktif milik orang perorangan dan/atau badan usaha perorangan yang memenuhi kriteria usaha mikro. Usaha mikro ada usaha produktif yang memiliki kekayaan bersih paling banyak Rp50.000.000,00 (lima puluh juta rupiah) tidak termasuk tanah dan bangunan tempat usaha; atau memiliki hasil penjualan tahunan paling banyak $\mathrm{Rp300} .000 .000,00$ (tiga ratus juta rupiah).

12 Ibid., hlm. 91.

13 Muhammad Djumhana dan R. Djubaedillah, Hak Milik Intelektual Sejarah Teori dan Prakteknya di Indonesia, Bandung: Citra Aditya Bakti, 2003, hlm.170.

14 Khoirul Hidayah, Hukum Hak Kekayaan Intelektual, Malang: Setara Press, 2017, hlm. 54.

15 Muhammad Djumhana dan R. Djubaedillah, Op.Cit.

16 Booklet Kekayaan Intelektual, Direktorat Jenderal Kekayaan Intelektual Kementerian Hukum dan HAM RI. 17 Ibid.

18 https://statistik.dgip.go.id/statistik/production/merek_umkm.php, diakses pada tanggal 7 Mei 2018. 
b. Usaha Kecil

Usaha Kecil adalah usaha ekonomi produktif yang berdiri sendiri, yang dilakukan oleh orang perorangan atau badan usaha yang bukan merupakan anak perusahaan atau bukan cabang perusahaan yang dimiliki, dikuasai, atau menjadi bagian baik langsung maupun tidak langsung dari Usaha Menengah atau Usaha Besar yang memenuhi kriteria Usaha Kecil sebagaimana diatur dalam Undang-Undang ini. Kriteria Usaha Kecil yaitu memiliki kekayaan bersih lebih dari Rp 50.000.000,00 (lima puluh juta rupiah) sampai dengan paling banyak Rp500.000.000,00 (lima ratus juta rupiah) tidak termasuk tanah dan bangunan tempat usaha; atau memiliki hasil penjualan tahunan lebih dari Rp300.000.000,00 (tiga ratus juta rupiah) sampai dengan paling banyak Rp2.500.000.000,00 (dua milyar lima ratus juta rupiah).

c. Usaha Menengah

Usaha Menengah adalah usaha ekonomi produktif yang berdiri sendiri, yang dilakukan oleh orang perorangan atau badan usaha yang bukan merupakan anak perusahaan atau cabang perusahaan yang dimiliki, dikuasai, atau menjadi bagian baik langsung maupun tidak langsung dengan Usaha Kecil atau Usaha Besar dengan jumlah kekayaan bersih atau hasil penjualan tahunan sebagaimana diatur dalam Undang-Undang ini. Kriteria Usaha Menengah yaitu memiliki kekayaan bersih lebih dari $\mathrm{Rp} 500.000 .000,00$ (lima ratus juta rupiah) sampai dengan paling banyak Rp10.000.000.000,00 (sepuluh milyar rupiah) tidak termasuk tanah dan bangunan tempat usaha; atau memiliki hasil penjualan tahunan lebih dari Rp2.500.000.000,00 (dua milyar lima ratus juta rupiah) sampai dengan paling banyak Rp50.000.000.000,00 (lima puluh milyar rupiah).

Berdasarkan pada fungsi dari pendaftaran Merek sebagaimana telah diuraikan khususnya terhadap merek UMKM, dan dikarenakan timbulnya perlindungan merek UMKM dengan cara pendaftaran merek akan lebih memotivasi kerja dan berimplikasi positif dalam meningkatkan daya saing sehingga meningkatkan pendapatan pelaku usaha UMKM. Dengan demikian, maka perlu dilakukan suatu upaya untuk meningkatkan persentase pendaftaran merek industri UMKM.

\section{Upaya Perlindungan Hukum terhadap Merek Industri UMKM di Indonesia}

Undang-Undang Merek No. 20 tahun 2016 tentang Merek dan Indikasi Geografis tidak banyak membahas terkait dengan Merek UMKM di Indonesia. Penyebutan terkait dengan Merek UMKM tertuang di dalam konsideran huruf a UU Merek 2016 yang berisikan "bahwa di dalam era perdagangan global, sejalan dengan konvensi internasional yang telah diratifikasi Indonesia, peranan Merek dan Indikasi Geografis menjadi sangat penting terutama dalam menjaga persaingan usaha yang sehat, berkeadilan, pelindungan konsumen, serta pelindungan Usaha Mikro Kecil dan Menengah, dan industri dalam negeri;". ${ }^{19}$

Berdasarkan konsideran tersebut, dapat diketahui bahwa fokus dari UU Merek 2016 adalah memberikan kepastian hukum dan perlindungan terutama kepada konsumen dan pelaku usaha dalam negeri, dan menjaga suatu persaingan usaha yang sehat. Hanya saja, persaingan usaha yang sehat hanya bisa dapat terjadi apabila para industri besar tidak memanfaatkan posisi dominannya untuk menekan industri UMKM melainkan mereka harus bisa bersinergi dalam menjalankan suatu roda perekonomian secara bersama-sama tanpa melakukan monopoli.

Keberadaan UU Merek 2016 diharapkan bisa menjadi salah satu cara pemerintah dalam melindungi usaha UMKM melalui perlindungan kekayaan intelektualnya yang berupa Merek. Dengan adanya pengakuan Merek yang diberikan kepada pelaku usaha UMKM maka industri besar ataupun para pelaku usaha yang memiliki itikad tidak baik, tidak serta merta dapat mengambil kekayaan intelektual milik pelaku usaha UMKM karena kepemilikan Merek yang terdaftar diakui dan dilindungi oleh pemerintah. Apabila ada sengketa yang lahir akibat adanya sengketa kepemilikan Merek, pemerintah hanya akan

19 Konsideran Undang-Undang No. 20 tahun 2016 tentang Merek dan Indikasi Geografis. 
mengacu sertifikat Merek sebagai bukti kepemilikan hak atas Merek, ${ }^{20}$ kecuali terjadi pembatalan hak atas merek berdasarkan gugatan merek yang dilakukan oleh salah satu pihak di pengadilan Niaga.

Kemudian sebagai upaya perlindungan hukum terhadap merek industri UMKM di Indonesia dilakukan dengan cara meningkatkan industri UMKM untuk mendaftarkan merek oleh pelaku UMKM. dikarenakan industri UMKM hanya akan mendapatkan perlindungan hukum merek apabila telah mendaftarkan mereknya. Upaya yang telah dilakukan yakni dengan cara:

a. Biaya Registrasi Merek UMKM yang Lebih Murah Dibandingkan Merek Non-UMKM

Kecilnya pendaftar Merek UMKM tidak membuat pemerintah tinggal diam. Pemerintah melalui Dirjen KI terus mendorong untuk meningkatkan pendaftaran Merek dari industri UMKM dengan membebankan biaya yang jauh lebih murah dibandingkan dengan pendaftar Merek Non UMKM. ${ }^{21}$ Hal tersebut menunjukkan kepedulian pemerintah untuk meningkatkan perkembangan bisnis UMKM dengan menjaga kekayaan intelektual dari para pelaku bisnis UMKM.

Sebuah merek terdaftar dilindungi sehingga orang lain tidak dapat memakainya dan akan mendapatkan perlindungan selama sepuluh (10) tahun dari tanggal penerimaan pendaftaran sebagaimana diatur dalam Pasal 35 UU No. 20 tahun 2016 tentang Merek dan Indikasi Geografis. Jangka waktu ini dapat diperpanjang untuk masa yang tidak ditentukan selama sepuluh (10) tahun dengan pembayaran biaya. Namun, pemilik, harus mengajukan perpanjangan 12 bulan sebelum merek tersebut berakhir. Merek akan diperpanjang masa berlakunya hanya jika pemilik masih memakai merek tersebut dalam perdagangan barang dan/atau jasa. ${ }^{22}$

Dirjen KI memberikan perlakuan khusus bagi industri UMKM dalam mendukung industri UMKM untuk mendaftarkan merek yakni dengan memberikan pembedaan harga registrasi yang lebih murah dibandingkan dengan pelaku usaha umum. Berikut disajikan perbandingan harga registrasi permohonan pendaftaran merek antara merek UMKM dan merek umum.

Tabel 1. Permohonan Pendaftaran Merek

\begin{tabular}{lclc}
\hline \multicolumn{1}{c}{ Merek UMKM } & Tarif Perkelas (Rp) & \multicolumn{1}{c}{ Merek Umum } & Tarif Perkelas (Rp) \\
\hline $\begin{array}{l}\text { Secara elektronik } \\
\text { (online) }\end{array}$ & $500.000,-$ & $\begin{array}{l}\text { Secara elektronik } \\
\text { (online) }\end{array}$ & $1.800 .000,-$ \\
$\begin{array}{l}\text { Secara non elektronik } \\
\text { (manual) }\end{array}$ & $600.000,-$ & $\begin{array}{l}\text { Secara non elektronik } \\
\text { (manual) }\end{array}$ & $2.000 .000,-$ \\
\hline
\end{tabular}

Sumber: http://dgip.go.id/tarif-merek diakses tanggal 7 Mei 2018

Tidak hanya terhadap permohonan pendaftaran merek saja, tetapi juga terhadap biaya perpanjangan perlindungan merek atau merek kolektif terdaftar antara merek UMKM dan umum juga diberikan perbedaan harga. Berikut disajikan perbandingan harga registrasi perpanjangan perlindungan merek antara merek UMKM dan merek umum.

Tabel 2. Biaya perpanjangan perlindungan merek dalam jangka waktu 6 (enam) bulan sebelum atau sampai dengan berakhirnya perlindungan merek

\begin{tabular}{|c|c|c|c|}
\hline Merek UMKM & Tarif Perkelas (Rp) & Merek Umum & Tarif Perkelas (Rp) \\
\hline $\begin{array}{l}\text { Secara elektronik } \\
\text { (online) }\end{array}$ & $1.000 .000,-$ & $\begin{array}{l}\text { Secara elektronik } \\
\text { (online) }\end{array}$ & $2.250 .000,-$ \\
\hline $\begin{array}{l}\text { Secara non elektronik } \\
\text { (manual) }\end{array}$ & $1.200 .000,-$ & $\begin{array}{l}\text { Secara non elektronik } \\
\text { (manual) }\end{array}$ & $2.500 .000,-$ \\
\hline
\end{tabular}

Sumber: http://dgip.go.id/tarif-merek diakses tanggal 7 Mei 2018

$20 \quad$ Pasal 1 angka 5 jo. Pasal 3 Undang-Undang No. 20 tahun 2016 tentang Merek dan Indikasi Geografis.

21 PP Nomor 45 Tahun 2016 tentang Jenis dan Tarif atas Jenis Penenerimaan Negara Bukan Pajak yang Berlaku pada Kementerian Hukum dan Hak Asasi Manusia.

22 Tim Lindsey, Hak Kekayaan Intelektual, Bandung: Alumni, 2005, hlm. 144. 
Tabel 3. Biaya perpanjangan perlindungan merek dalam jangka waktu 6 (enam) bulan setelah berakhirnya perlindungan merek

\begin{tabular}{lclc}
\hline \multicolumn{1}{c}{ Merek UMKM } & Tarif Perkelas (Rp) & \multicolumn{1}{c}{ Merek Umum } & Tarif Perkelas (Rp) \\
\hline $\begin{array}{l}\text { Secara elektronik } \\
\text { (online) }\end{array}$ & $1.500 .000,-$ & $\begin{array}{l}\text { Secara elektronik } \\
\text { (online) }\end{array}$ & $3.000 .000,-$ \\
$\begin{array}{l}\text { Secara non elektronik } \\
\text { (manual) }\end{array}$ & $1.800 .000,-$ & $\begin{array}{l}\text { Secara non elektronik } \\
\text { (manual) }\end{array}$ & $4.000 .000,-$ \\
\hline
\end{tabular}

Sumber: http://dgip.go.id/tarif-merek diakses tanggal 7 Mei 2018

\section{b. Kerjasama antara Ditjen KI Kementerian Hukum dan Ham dan Kementerian Koperasi dan UMKM}

Upaya yang telah dilakukan untuk memberikan perlindungan Merek dagang produksi industri UMKM diadakan Kerjasama antara Departemen Hukum dan HAM RI dengan Kementrian Koperasi dan Usaha Kecil Dan Menengah RI Nomor M-10-UM .06.07.TH 2006 tentang Peningkatan Pemahaman dan Pemanfaatan Sistem Hak Kekayaan Intelektual yang di dalamnya terdapat perlindungan merek dagang bagi Koperasi dan UMKM. Adapun pertimbangan diadakan kerjasama tersebut adalah sebagai berikut:

1) UMKM merupakan salah satu pelaku usaha yang memiliki kontribusi yang nyata dalam perekonomian nasional.

2) Pengetahuan dan pemahaman mengenai keberadaan dan pentingnya pemanfaatan sistim Hak Kekayaan Intelektual (khususnya Hak Merek) di kalangan pelaku UMKM sektor industri baik makanan, miniman maupun barang-barang produksi olahan rumah tangga masih perlu disosialisasikan.

3) Koordinasi dan kerjasama yang sinergi antara para pihak dan upaya peningkatan penyebarluasan, pemahaman dan pemanfaatan sistem Hak Kekayaan Intelektual belum optimal dalam perlindungan merek dagang produk makanan.

Tujuan diadakan kerjasama antara Departemen Hukum dan HAM RI dengan Kementrian Negara Koperasi dan Usaha Kecil Menengah adalah:

1) Meningkatkan pengetahuan dan pemahaman serta pemanfaatan sistim HKI khususnya merek dagang dikalangan pelaku UMKM.

2) Mewujudkan UMKM berorientasi HKI khususnya Hak Merek, memiliki kualitas dan daya saing yang tinggi dalam persaingan global.

3) Meningkatkan koordinasi dan kerjasama yang sinergis dan produktif antara para pihak dalam mengembangkan UMKM dan memberdayakan sistim Hak Kekayaan Intelektual ( HKI ) nasional.

\section{c. Pemberian Intensif Pembiayaan Pendaftaran Merek UMKM}

Dasar hukum Keputusan Direktur Jenderal Hak Kekayaan Intelektual Kementerian Hukum dan Hak Asasi Manusia RI Nomor HKI-09.OT.03.01 Tahun 2013 tentang Insentif Hak Kekayaan Intelektual Bagi Sekolah Menengah Perguruan Tinggi, Usaha Mikro dan Usaha Kecil serta Warga Binaan Pemasyarakatan Tahun 2013. Pemberian insentif berupa pemberian pembiayaan pendaftaran pengajuan permohonan Hak Kekayaan Intelektual yakni merek baik berupa gambar, nama, kata, huruf-huruf, angka-angka, susunan warna atau kombinasi dari unsur-unsur tersebut yang memiliki daya pembeda dan digunakan dalam kegiatan barang atau jasa.

Adapun ruang lingkup pemberian insentif merek mencakup pengajuan permohonan pendaftaran merek untuk maksimal 3 (tiga) macam barang atau jasa dalam 1 (satu) kelas setiap permohonannya. Pemberian insentif ditujukan bagi Usaha Mikro dan Usaha Kecil dengan persyaratan:

1) Membawa surat pernyataan yang menyatakan sebagai UMKM yang dibubuhi materai secukupnya. 
Upaya Perlindungan Hukum Terhadap ...

2) Syarat permohonan pengajuan pendaftaran berdasarkan undang-undang merek, yaitu:

- Mengisi formulir dalam bahasa Indonesia

- $\quad$ Foto copy KTP (3 lembar)

- $\quad$ Akta Badan Hukum/TBN (2 rangkap dilegalisasi oleh Notaris)

- $\quad$ Contoh etiket merek ukuran minimal 2x2 cm, maksimal 9x9 cm (28 helai)

- $\quad$ Surat pernyataan disertai materai Rp. 6000,-

3) Belum pernah mendapat bantuan atau insentif dari pihak manapun.

4) Karya yang dihasilkan memenuhi kriteria perlindungan hak kekayaan intelektual dan berguna bagi masyarakat.

5) Surat Pengantar yang berasal dari Kantor Wilayah Kementerian Hukum dan HAM, jika pengajuan permohonan melalui Kantor Wilayah Kementerian Hukum dan HAM.

6) Surat Rekomendasi yang berasal dari Kementerian atau Dinas jika berasal dari Kementerian atau Dinas.

Akan tetapi pelaksanaan pengajuan permohonan pemberian insentif selama 12 hanya diadakan (dua belas) bulan terhitung tanggal 1 Januari 2013 sampai dengan 31 Desember 2013.

\section{d. Pendaftaran Merek Kolektif Industri UMKM}

Di Indonesia pelaku UMKM seringkali memperjual belikan suatu barang atau jasa dengan suatu ciri khas yang sama oleh beberapa pelaku UMKM lainnya. Sehingga, pemerintah melalui UU No. 20 tahun 2016 tentang Merek dan Indikasi Geografis memfasilitasi perlindungan Merek secara kolektif. Berdasarkan penjelasan UU No. 20 tahun 2016 tentang Merek dan Indikasi Geografis, Merek kolektif adalah Merek yang digunakan pada barang dan/atau jasa dengan karakteristik yang sama mengenai sifat, ciri umum, dan mutu barang atau jasa serta pengawasannya yang akan diperdagangkan oleh beberapa orang atau badan hukum secara bersama-sama untuk membedakan dengan barang dan/atau jasa sejenis lainnya. ${ }^{23}$

Merek kolektif diatur dalam Article 7 bis the Paris Convention for the Protection of Industrial Property Rights (1883/1967). Berdasarkan Article 7 Paris Convention negara anggota harus menerima pendaftaran merek kolektif yang dimiliki oleh asosiasi dimana eksistensinya tidak bertentangan dengan negara hukum asal, meskipun asosiasi tersebut tidak memiliki suatu pendirian komersial atau industrial di negara tersebut. Setiap negara menilai suatu persyaratan tertentu dimana merek kolektif dilindungi atau mungkin ditolak pendaftarannya jika merek kolektif tersebut bertentangan dengan kepentingan umum.

Di Indonesia, merek kolektif diatur dalam Pasal 46 sampai dengan Pasal 51 UndangUndang Nomor 20 Tahun 2016 tentang Merek dan Indikasi Geografis. Tujuan penggunaan merek kolektif adalah untuk menyederhanakan penyelesaian permintaan pendaftaran. Misalnya, jika sepuluh pengusaha masing-masing memproduksi jenis barang atau jasa, maka mereka harus mengajukan permintaan pendaftaran untuk melindungi setiap barang atau jasa yang dimaksud. Padahal masing-masing barang atau jasa yang diproduksi dan diperdagangkan tersebut mempunyai karakteristik yang sama, maka dalam hal tersebut dimungkinkan untuk menggunakan satu merek saja. Terhadap semua jenis barang atau jasa, cukup diajukan satu permintaan pendaftaran merek untuk mereka gunakan secara kolektif. Dengan demikian, para pengusaha khususnya pelaku UMKM dapat menghemat biaya, waktu dan tenaga untuk memproses permintaan pendaftaran merek. ${ }^{24}$

Merek kolektif merupakan salah satu jalan keluar yang diberikan oleh pemerintah terhadap para pelaku usaha UMKM di Indonesia. Jika mengacu kepada bunyi pasal 1 angka 4, maka pada prinsipnya Merek kolektif adalah Merek yang dipergunakan oleh komunitas pelaku usaha yang memperdagangkan suatu produk barang ataupun jasa yang sama. Para

23 Pasal 1 angka 4 Undang-Undang No. 20 tahun 2016 tentang Merek dan Indikasi Geografis.

24 Yahya Harahap, Tinjauan Merek Secara Umum dan Hukum Merek di Indonesia Berdasarkan UndangUndang Nomor 19 Tahun 1992, Bandung: PT Citra Aditya Bakti, 1996, hlm. 604. 
pelaku usaha tidak perlu mendaftarkan atau membangun merek secara individual melainkan dibangun secara bersama melalui beberapa orang ataupun beberapa badan usaha.

\section{Simpulan}

Berdasarkan pada uraian tersebut di atas, maka dapat disimpulkan bahwa upaya dalam memberikan perlindungan merek terhadap industri UMKM adalah dengan cara mendaftarkan merek UMKM. Sehingga, dikarenakan kriteria pelaku usaha industri UMKM memiliki keterbatasan baik dari modal, aset maupun hasil penjualan tahunan jika dibandingkan dengan pelaku usaha Non-UMKM, oleh karenanya pemerintah memberikan kemudahan bagi pelaku industri UMKM untuk mendaftarkan merek, yaitu melalui kebijakan biaya registrasi merek UMKM yang lebih murah dibandingkan merek Non-UMKM, melakukan kerasama antara Dirjen KI Kementerian Hukum dan HAM dan Kementerian Koperasi dan UMKM, memberikan insentif pembiayaan pendaftaran pendaftaran merek UMKM, serta pendaftaran merek kolektif industri UMKM.

\section{Daftar Pustaka}

\section{Buku}

Booklet Kekayaan Intelektual. Direktorat Jenderal Kekayaan Intelektual Kementerian Hukum dan HAM RI.

Djumhana, Muhammad dan R. Djubaedillah. 2003. Hak Milik Intelektual Sejarah Teori dan Prakteknya di Indonesia. Bandung: Citra Aditya Bakti.

Harahap, Yahya . 1996. Tinjauan Merek Secara Umum dan Hukum Merek di Indonesia Berdasarkan Undang-Undang Nomor 19 Tahun 1992. Bandung: PT Citra Aditya Bakti.

Hidayah, Khoirul. 2017. Hukum Hak Kekayaan Intelektual. Malang: Setara Press.

Lindsey, Tim. 2005. Hak Kekayaan Intelektual. Bandung: Alumni.

Sardjono, Agus. "Pelaksanaan Perlindungan Hukum Merek Untuk Pengusaha UKM Batik Di Pekalongan, Solo, dan Yogyakarta". Jurnal Hukum dan Pembangunan. Volume 4 Oktober-Desember (2013).

Sutedi, Adrian. 2009. Hak Atas Kekayaan Intelektual. Jakarta: Sinar Grafika.

\section{Peraturan Perundang-Undangan}

Undang-Undang No. 20 tahun 2016 tentang Merek dan Indikasi Geografis.

PP Nomor 45 Tahun 2016 tentang Jenis dan Tarif atas Jenis Penenerimaan Negara Bukan Pajak yang Berlaku pada Kementerian Hukum dan Hak Asasi Manusia.

\section{Internet}

http://www.kemenperin.go.id/artikel/14200/Kontribusi-UMKM-Naik

https://ekonomi.inilah.com/read/detail/2443605/umkm-berbadan-hukum-masih-kecil

https://statistik.dgip.go.id/statistik/production/merek_umkm.php 